\title{
Comparative study on chemical composition of various biomass species
}

\section{AUTHOR(S):}

Rabemanolontsoa, Harifara; Saka, Shiro

\section{CITATION:}

Rabemanolontsoa, Harifara ...[et al]. Comparative study on chemical composition of various biomass species. RSC Advances 2013, 3(12): 3946-3956

\section{ISSUE DATE:}

2013-01

URL:

http://hdl.handle.net/2433/187116

\section{RIGHT:}

(c) The Royal Society of Chemistry 2013; この論文は出版社版でありませ ん。引用の際には出版社版をご確認ご利用ください。; This is not the published version. Please cite only the published version. 


\title{
Comparative Study on Chemical Composition of Various Biomass Species
}

\author{
Harifara Rabemanolontsoa and Shiro Saka * \\ Department of Socio-Environmental Energy Science, Graduate School of Energy Science, Kyoto University, \\ Yoshida-honmachi, Sakyo-ku, Kyoto 606-8501, Japan. Fax/ Tel: +81-75-753-4738; *Email:saka@energy.kyoto-u.ac.jp
}

In this study, the chemical composition of 32 samples coming from 29 different biomass species including a gymnosperm, 2 dicotyledonous angiosperms, 17 monocotyledonous angiosperms and 9 algae species was successfully determined using an established method applicable to analyze various biomass species. The obtained data allowed a direct comparison of the biomass in their chemical composition. It was, thus, revealed that although the chemical composition differed from one species to another, and even from different parts of the same plants, similar trends were found in the composition of biomass species belonging to the same taxonomic group. Based on those results, it was clarified that the chemical composition of a biomass sample is related to its taxonomy. Therefore, typical chemical composition for each taxonomic group was proposed and the potential of each group for different biorefinery platforms could be successfully established.

\section{Introduction}

Increasing energy security and mitigating climate change require the substitution of petroleum-based and nuclear-based productions to fulfill human needs for energy, chemicals and materials. One important supply of renewable resource for energy, chemicals and materials is biomass and it became a worldwide goal to develop biobased products through integrated biorefinery systems.

Biomass consists of all living organisms and their wastes. The world annual primary production of biomass was evaluated by Whittaker to be $1,855\left(10^{9}\right)$ dried tons. ${ }^{3}$ In 2009 , the United Nations Environment Programme (UNEP) reported that 140 $\left(10^{9}\right)$ tons of biomass is generated every year from agricultural land, ${ }^{4}$ equivalent to approximately 50 billion tons of fossil oil. ${ }^{5}$ The large quantities of available biomass all over the world can, therefore, be converted to a massive amount of energy and raw materials.

For the best use of those feedstocks, their chemical composition is known to be a key factor. Indeed, chemical composition is a unique fundamental code which characterizes and determines the properties, quality, potential applications and environmental problems related to any applications. Therefore, one of the fundamental aspects related to biomass use is to extend and improve the basic knowledge on composition and properties of biomass. ${ }^{6}$

Chemical composition of biomass is a formidable challenge due to the various origins, forms and complexity of the materials, as can be seen in Fig. 1 which shows a simplified evolution and diversity of various biomass species. Data on chemical composition for biomass varieties have been reported in almost all studies on biomass transformation. As a result, a huge amount of data exists and some similarities or differences in common chemical characteristics based on literature review were reported. ${ }^{7}$ Additionally, a database gathering a multitude of studies which report chemical composition and properties of different feedstocks was settled by the US Department of Energy.

8 Despite such available information, comparison of the different results from literature review would be erroneous since the analytical methods and basis differ from an author to another and from a biomass species to another.

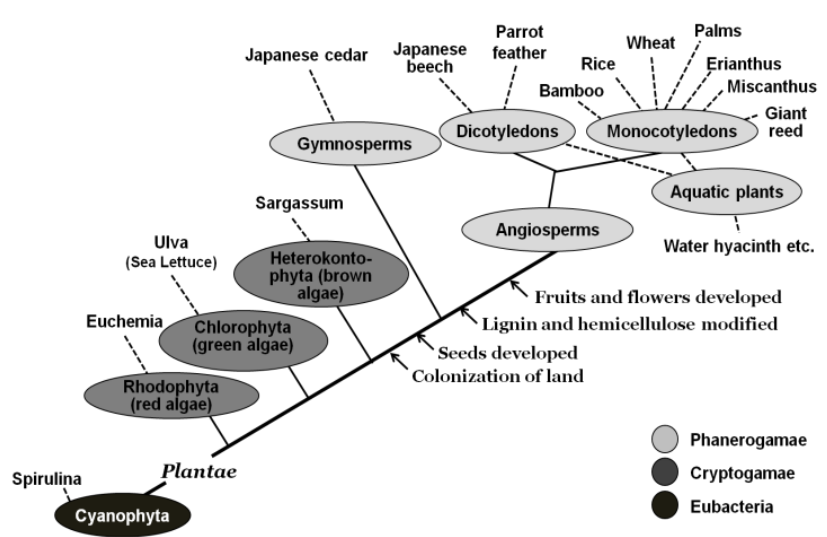

Fig. 1 Simplified evolution and diversity of various biomass species $^{1,2}$

Woody biomass were analyzed according to wood analytical procedures, ${ }^{9-11}$ whereas agricultural residues, grasses species $^{12}$ and algae have been mostly studied using feed and forage analytical procedures. ${ }^{13-15}$ Terms and definition of the chemical components are also different between the methods: wood analytical method determines cellulose, hemicellulose and lignin, whereas feed and forage analytical procedures result in neutral detergent fiber, acid detergent fiber and crude fiber.

For those reasons, there exists a problem of consistency when comparing the data from the literature. Furthermore, direct comparisons of different biomass species such as wood, herbaceous, aquatic plants and marine algae in their chemical composition are quite few at present.

Such issues show that additional works on detailed comparisons of biomass in their chemical composition, under the same method and basis is absolutely needed. On this line of study, an analytical methodology applicable to characterize various biomass species in their chemical composition was established. ${ }^{16}$ Thus, the purpose of the present work was to elucidate the 
chemical composition of a wide range of biomass species, using the same method and basis. The chemical components were 
Table 1 Various biomass samples studied in this work

\begin{tabular}{|c|c|c|c|c|c|c|c|c|c|}
\hline \multicolumn{5}{|c|}{ Taxonomy } & \multirow{2}{*}{ Scientific name } & \multirow{2}{*}{ Common name } & \multirow{2}{*}{$\begin{array}{c}\text { Sample } \\
\text { No. }\end{array}$} & \multirow{2}{*}{$\begin{array}{l}\text { Sampling } \\
\text { time }\end{array}$} & \multirow{2}{*}{ Sampling site } \\
\hline Kingdom & $\begin{array}{ll} & \text { Subkingdom }\end{array}$ & Division & Class & Family & & & & & \\
\hline \multirow[t]{31}{*}{$\overline{\text { Plantae }}$} & Phanerogamae & Gymnosperm & & Cupressaceae & Cryptomeria japonica & Japanese cedar & 1 & $12 / 2000$ & Kyoto, Japan \\
\hline & & Angiosperm & Dicotyledon & Fagaceae & Fagus crenata & Japanese beech & 2 & $11 / 2000$ & Kyoto, Japan \\
\hline & & & & Haloragaceae & $\begin{array}{l}\text { Myriophyllum aquaticum } \\
\text { (aquatic plant) }\end{array}$ & Parrot feather & 3 & $04 / 2010$ & Moriyama, Shiga, Japan \\
\hline & & & Monocotyledon & Poaceae (Gramineae) & Phyllostachys heterocycla & Bamboo & 4 & $06 / 2008$ & Kyoto, Japan \\
\hline & & & & & Oryza sativa & Rice straw & 5 & $10 / 2007$ & Aichi, Japan \\
\hline & & & & & & Rice husk & 6 & & \\
\hline & & & & & Triticum aestivum & Wheat straw & 7 & $08 / 2007$ & Aichi, Japan \\
\hline & & & & & Zea mays & Corn leaves & 8 & $08 / 2010$ & Aomori, Japan \\
\hline & & & & & & Corn cob & 9 & & \\
\hline & & & & & Erianthus arundinaceus & Erianthus & 10 & $09 / 2009$ & $\begin{array}{l}\text { Nakhon Si Thammarat, } \\
\text { Thailand }\end{array}$ \\
\hline & & & & & Miscanthus sinensis & Miscanthus & 11 & $09 / 2009$ & Kyoto, Japan \\
\hline & & & & & Saccharum officinarum & Bagasse & 12 & $04 / 2008$ & Okinawa, Japan \\
\hline & & & & & & Sugarcane leaves & 13 & & \\
\hline & & & & & Phragmites australis & Common reed & 14 & $04 / 2011$ & $\begin{array}{l}\text { Omihachiman, Shiga, } \\
\text { Japan }\end{array}$ \\
\hline & & & & & Arundo donax & Giant reed & 15 & $05 / 2011$ & Seattle, USA \\
\hline & & & & Aracaceae & Elaeis guineensis & Oil palm trunk & 16 & $08 / 2008$ & Johor Bahru, Malaysia \\
\hline & & & & (Palmae) & Nypa fruticans & Nipa frond & 17 & $04 / 2009$ & $\begin{array}{l}\text { Nakhon Si Thammarat, } \\
\text { Thailand }\end{array}$ \\
\hline & & & & & Borassus flabellifer & Sugar palm frond & 18 & 07/2009 & $\begin{array}{l}\text { Nakhon Si Thammarat, } \\
\text { Thailand }\end{array}$ \\
\hline & & & & $\begin{array}{l}\text { Pontederiaceae (aquati } \\
\text { plants) }\end{array}$ & c Eichhornia crassipes & Water hyacinth & 19 & $10 / 2011$ & Moriyama, Shiga, Japan \\
\hline & & & & $\begin{array}{l}\text { Potamogetonaceae } \\
\text { (aquatic plants) }\end{array}$ & Potamogeton maackianus & Sennin-mo & 20 & $07 / 2010$ & Otsu, Shiga,Japan \\
\hline & & & & Hydrocharitaceae & Egeria densa & Okanada-mo & 21 & $07 / 2010$ & Otsu, Shiga,Japan \\
\hline & & & & (aquatic plants) & Hydrilla verticillata & Kuro-mo & 22 & $07 / 2010$ & Moriyama, Shiga, Japan \\
\hline & & & & & Elodea nuttallii & Kokanada-mo & 23 & $07 / 2010$ & Moriyama, Shiga, Japan \\
\hline & Cryptogamae & Heterokontophyta & Phaeophyceae & Sargassaceae & Sargassum horneri & Akamoku & 24 & $07 / 2010$ & Kyoto, Japan \\
\hline & & (brown algae) & & & Sargassum sp. & Sargassum & 25 & $01 / 2011$ & $\begin{array}{l}\text { Oki Island, Shimane, } \\
\text { Japan }\end{array}$ \\
\hline & & Chlorophyta (green & Ulvophyceae & Ulvaceae & Ulva lactuca & Sea lettuce & 26 & $08 / 2010$ & Nagasaki, Japan \\
\hline & & algae) & & & Chladophora sp. & Chladophora & 27 & $04 / 2011$ & Tuléar, Madagascar \\
\hline & & & Bryopsidophyceae & Caulerpaceae & Caulerpa taxifolia & Caulerpa & 28 & $12 / 2010$ & Okinawa, Japan \\
\hline & & & & & Caulerpa lentillifera & Sea grape & 29 & 08/2010 & Okinawa, Japan \\
\hline & & & Trebouxiophyceae & Chlorellaceae & Chlorella vulgaris & Chlorella & 30 & $08 / 2010$ & Fukuoka, Japan \\
\hline & & $\begin{array}{l}\text { Rhodophyta } \\
\text { (red algae) }\end{array}$ & Rhodophyceae & Solieraceae & Eucheumia sp. & Euchemia & 31 & $04 / 2011$ & Tuléar, Madagascar \\
\hline Bacteria & Eubacteria & $\begin{array}{l}\text { Cyanophyta } \\
\text { (blue-green algae) }\end{array}$ & Cyanophyceae & Pseudanabaenaceae & Spirulina sp. & Spirulina & 32 & $04 / 2011$ & Tuléar, Madagascar \\
\hline
\end{tabular}


quantitatively investigated for comparison among different biomass species.

\section{Materials and methods}

\subsection{Plant materials}

Table 1 shows the taxonomy of the biomass samples studied in this work, and their sampling details are also provided. As gymnosperm species, Japanese cedar (Cryptomeria japonica) was selected to be one of the representative one in Japan, while Japanese beech (Fagus crenata) was selected as one of the dicotyledonous angiosperms, together with parrot feather (Myriophyllum aquaticum). Furthermore, Gramineae monocotyledonous angiosperms were selected such as bamboo (Phyllostachys pubescens), rice straw and husk (Oryza sativa), wheat straw (Triticum aestivum), corn leaves and cob (Zea mays), erianthus (Erianthus arundinaceus), miscanthus (Miscanthus sinensis), sugarcane bagasse and leaves (Saccharum officinarum), common reed (Phragmites australis), giant reed (Arundo donax). In addition, palm monocotyledonous angiosperms such as oil palm (Elaeis guineensis), nipa palm (Nypa fruticans) and sugar palm (Borassus flabellifer) were studied.

Besides, monocotyledonous invasive aquatic plants such as water hyacinth (Eichhornia crassipes), sennin-mo (Potamogeton maackianus), okanada-mo (Egeria densa), kuro-mo (Hydrilla verticillata), as well as kokanada-mo (Elodea nuttallii) were collected from Lake Biwa in Japan. Also, algae species such as akamoku (Sargassum horneri), sargassum (Sargassum sp.), sea lettuce (Ulva lactuca), chladophora (Chladophora sp.), caulerpa (Caulerpa taxifolia), sea grape (Caulerpa lentillifera), chlorella (Chlorella vulgaris), euchemia (Euchemia sp.), spirulina (Spirulina sp.) were collected from different places all over the world as detailed in Table 1, to be analyzed and compared in their chemical composition.

\subsection{Analytical methods for the determination of chemical composition and calorific value}

These collected samples were air-dried, milled with a Wiley mill (1029-C, Yoshida Seisakusho Co., Ltd.), and sieved to retain particles of $150-500 \mu \mathrm{m}$ in size (30-100 mesh).

The samples were, then, oven-dried and the summative chemical composition was determined according to the method detailed in Fig. 2. ${ }^{16}$ In brief, ash was determined after incineration of the oven-dried samples at $600^{\circ} \mathrm{C}$ for $4 \mathrm{~h}$. For additional analyses, the samples were extracted with acetone. On the extractives-free samples, holocellulose and lignin were, respectively, determined by modified Wise method ${ }^{17}$ and modified Klason method. ${ }^{18}$ Both were then ash- and proteincorrected by subtracting ash and protein contents of the residues from the total residues yielded. Holocellulose was additionally corrected for its residual lignin content. ${ }^{17}$ Cellulose content was determined as $\alpha$-cellulose by extraction with $17.5 \%$ aqueous sodium hydroxide of the holocellulose powder ${ }^{19}$ and hemicellulose content was evaluated by difference between the corrected holocellulose and cellulose contents.

Additionally, monosaccharides composition was determined by a combined method. ${ }^{20}$ Glucose was quantified as hydrolysate from the Klason lignin procedure with $72 \%$ and subsequent $3 \%$
$\mathrm{H}_{2} \mathrm{SO}_{4}$ treatments, ${ }^{18}$ then analyzed with high-performance anionexchange chromatography (HPEAC, Dionex ICS-3000 system) equipped with CarboPac PA-1 column (4mm x 250mm), whereas the other neutral sugars and the uronic acids by acid methanolysis method $^{21}$ with slight modifications. In brief, $2 \mathrm{ml}$ of $2 \mathrm{M} \mathrm{HCl}$ in anhydrous methanol was poured to $10 \mathrm{mg}$ of extractive-free sample for methanolysis at $100{ }^{\circ} \mathrm{C}$ for $3 \mathrm{~h}$. Afterwards, the sample was cooled and $100 \mu \mathrm{l}$ was pipetted into a $1 \mathrm{ml}$ glass microtube which was, then, put into a desiccator and vacuumed overnight to remove the remaining methanol and $\mathrm{HCl}$. When the sample was completely dry, $500 \mu$ of pure deionized water was added. The resulting solution was diluted, if necessary, filtered with $0.45 \mu \mathrm{m}$ Millipore filter, and finally analyzed with highperformance anion-exchange chromatography (HPAEC) using CarboPac PA1 as column. As for xylose, the higher value among the results from sulphuric acid hydrolysis and acid methanolysis was taken.

Furthermore, in order to determine the phenylpropane units of lignin, alkaline nitrobenzene oxidation was performed on the extractives-free samples ${ }^{22}$ with slight modifications, where the oxidized products were silylated using trimethylchlorosilane (TMCS), bis(trimethylsilyl)trifluoroacetamide (BSTFA) and pyridine in a volumetric ratio of 2:1:7 and analyzed by gas chromatography with veratraldehyde as an internal standard.

In addition, starch and protein determinations from extractives-free samples were, respectively, completed by perchloric acid method ${ }^{23}$ and Kjeldahl nitrogen method by using a nitrogen factor of $6.25 .^{24}$

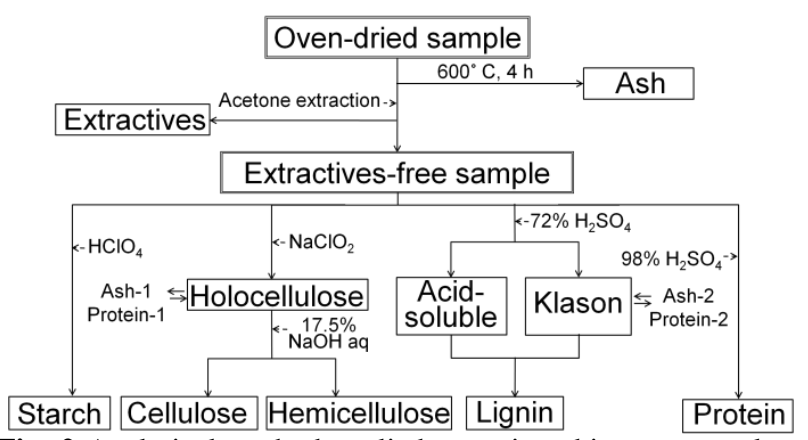

Fig. 2 Analytical method applied to various biomass samples to quantify their chemical composition ${ }^{16}$

The calorific values of the various biomass species were determined as their higher heating values (HHV) after complete combustion using an auto-calculating bomb calorimeter CA-4AJ, Shimadzu with a base temperature of $15^{\circ} \mathrm{C}$.

\subsection{Chemometrics}

Principal component analysis method (PCA) was used to plot the 32 analyzed samples according to their 7 chemical components which are cellulose, hemicellulose, lignin, protein, extractives, starch and ash. The software used for such multivariate analysis was GNU Octave. 
Table 2 Chemical composition and calorific value of the various biomass samples studied

\begin{tabular}{|c|c|c|c|c|c|c|c|c|c|c|c|c|}
\hline \multirow{3}{*}{ Family } & \multirow{3}{*}{$\begin{array}{l}\text { Sample } \\
\text { No. }\end{array}$} & \multirow{3}{*}{ Biomass } & \multicolumn{9}{|c|}{ Chemical composition ( $\mathrm{g} / \mathrm{kg}$ of the oven-dried biomass basis) } & \multirow{3}{*}{$\begin{array}{c}\text { Calorific } \\
\text { value } \\
(\mathrm{MJ} / \mathrm{kg})\end{array}$} \\
\hline & & & \multirow[b]{2}{*}{ Cellulose $^{\mathrm{a}}$} & \multirow{2}{*}{$\begin{array}{l}\text { Hemi- } \\
\text { cellulose }^{\mathrm{b}}\end{array}$} & \multicolumn{2}{|c|}{ Lignin } & \multirow[b]{2}{*}{ Protein } & \multirow[b]{2}{*}{ Extractives } & \multirow[b]{2}{*}{ Starch } & \multirow[b]{2}{*}{ Ash } & \multirow[b]{2}{*}{ Total } & \\
\hline & & & & & Klason & $\begin{array}{l}\text { Acid- } \\
\text { soluble }\end{array}$ & & & & & & \\
\hline $\begin{array}{l}\text { Cupressaceae } \\
\text { (softwood) }\end{array}$ & 1 & Japanese cedar & 379 & 227 & 328 & 3 & 5 & 34 & 1 & 3 & 980 & 19.35 \\
\hline $\begin{array}{l}\text { Fagaceae } \\
\text { (hardwood) }\end{array}$ & 2 & Japanese beech & 439 & 284 & 210 & 30 & 6 & 19 & 5 & 6 & 999 & 20.62 \\
\hline Poaceae & 4 & Bamboo & 394 & 311 & 193 & 13 & 18 & 38 & 11 & 12 & 990 & 20.32 \\
\hline \multirow[t]{8}{*}{ (Gramineae) } & 5 & Rice straw & 345 & 218 & 184 & 18 & 47 & 45 & 9 & 133 & 999 & 16.74 \\
\hline & 6 & Rice husk & 360 & 173 & 228 & 13 & 16 & 13 & 2 & 168 & 973 & 17.44 \\
\hline & 7 & Wheat straw & 371 & 340 & 180 & 20 & 13 & 22 & 5 & 37 & 988 & 18.86 \\
\hline & 11 & Miscanthus & 337 & 248 & 183 & 40 & 83 & 28 & 5 & 54 & 978 & 20.03 \\
\hline & 12 & Bagasse & 383 & 309 & 209 & 15 & 17 & 35 & 2 & 20 & 990 & - \\
\hline & 13 & $\begin{array}{l}\text { Sugarcane } \\
\text { leaves }\end{array}$ & 331 & 265 & 179 & 18 & 34 & 75 & 12 & 50 & 964 & - \\
\hline & 14 & Common reed & 344 & 284 & 185 & 17 & 26 & 26 & 3 & 86 & 971 & 19.32 \\
\hline & 15 & Giant reed & 416 & 242 & 225 & 24 & 11 & 33 & 4 & 32 & 987 & 20.06 \\
\hline \multirow{3}{*}{$\begin{array}{l}\text { Aracaceae } \\
\text { (Palmae) }\end{array}$} & 16 & Oil palm trunk & 306 & 284 & 243 & 39 & 6 & 36 & 29 & 41 & 984 & 19.11 \\
\hline & 17 & Nipa frond & 324 & 291 & 179 & 17 & 23 & 19 & 8 & 105 & 966 & 19.79 \\
\hline & 18 & $\begin{array}{l}\text { Sugar palm } \\
\text { frond }\end{array}$ & 317 & 313 & 191 & 18 & 30 & 45 & 10 & 50 & 974 & 18.27 \\
\hline \multirow{2}{*}{$\begin{array}{l}\text { Hydrocharitaceae } \\
\text { (aquatic plants) }\end{array}$} & 22 & Kuro-mo & 227 & 141 & 64 & 15 & 228 & 67 & 18 & 223 & 983 & 16.22 \\
\hline & 23 & Kokanada-mo & 436 & 93 & 61 & 15 & 137 & 52 & 23 & 158 & 975 & 15.58 \\
\hline Sargassaceae & 24 & Akamoku & 53 & 266 & 129 & 13 & 180 & 96 & 5 & 229 & 971 & 14.49 \\
\hline (brown algae) & 25 & Sargassum & 203 & 428 & 60 & 13 & 96 & 19 & 1 & 171 & 991 & 14.02 \\
\hline Ulvaceae & 26 & Sea lettuce & 80 & 421 & 30 & 3 & 120 & 41 & 7 & 257 & 959 & 15.88 \\
\hline (green algae) & 27 & Chladophora & 49 & 339 & 0 & 0 & 108 & 2 & 71 & 402 & 971 & 11.46 \\
\hline Caulerpaceae & 28 & Caulerpa & 102 & 354 & 29 & 8 & 261 & 65 & 8 & 167 & 994 & 16.28 \\
\hline (green algae) & 29 & Sea grape & 56 & 207 & 21 & 5 & 146 & 54 & 3 & 500 & 992 & 8.47 \\
\hline $\begin{array}{l}\text { Chlorellaceae } \\
\text { (green algae) }\end{array}$ & 30 & Chlorella & 50 & 424 & 0 & 0 & 423 & 9 & 1 & 76 & 983 & 23.48 \\
\hline $\begin{array}{l}\text { Solieraceae (red } \\
\text { algae) }\end{array}$ & 31 & Euchemia & 60 & 660 & 11 & 7 & 75 & 10 & 10 & 150 & 983 & 12.50 \\
\hline $\begin{array}{l}\text { Pseudanabaenaceae } \\
\text { (blue-green algae) }\end{array}$ & 32 & Spirulina & 0 & 296 & 0 & 0 & 502 & 30 & 1 & 144 & 973 & 19.52 \\
\hline
\end{tabular}

${ }^{\mathrm{a}}$ Cellulose $=\alpha$-Cellulose

${ }^{\mathrm{b}}$ Hemicellulose $=$ Holocellulose $-\alpha$-Cellulose $\quad($ Holocellulose was ash, lignin and protein-corrected) 


\section{Results and discussion}

\subsection{Chemical composition of various biomass species}

Table 2 shows the chemical composition of various biomass species, based on $\mathrm{g} / \mathrm{kg}$ of the oven-dried biomass basis. Chemical composition varies greatly among the analyzed biomass samples. Woody biomass samples ranked among the highest in the cellulose content with $379 \mathrm{~g} / \mathrm{kg}$ for Japanese cedar (No.1) and $439 \mathrm{~g} / \mathrm{kg}$ for Japanese beech (No.2). However, other non-woody biomass such as kokanada-mo (No.23), giant reed (No.15), bamboo (No.4), bagasse (No.12) and erianthus (No.10) had more or less similar cellulose contents to be, respectively, 436, 416, 394, 383 and $378 \mathrm{~g} / \mathrm{kg}$. Those lignocellulosic species have, therefore, high potential for cellulose applications. Cellulose in the Gramineae species (No.4-No.15) ranged from 268 to $416 \mathrm{~g} / \mathrm{kg}$, while it was between 306 and $324 \mathrm{~g} / \mathrm{kg}$ in the palm species (No.16-No.18) studied. In the algae (No.24-No.32), cellulose was equal to or below $203 \mathrm{~g} / \mathrm{kg}$.

In this study, polysaccharides other than cellulose were considered as hemicellulose and its content in the biomass species studied varied from 88 to $660 \mathrm{~g} / \mathrm{kg}$. Euchemia (No.31), Sargassum (No.25) and chlorella (No.30) presented the highest values with, respectively, 660, 428 and $424 \mathrm{~g} / \mathrm{kg}$. Although cellulose is the principal carbohydrate in higher plants, it was not the case in algae species (No.24-No.32) where hemicellulose, varying from 207 to $606 \mathrm{~g} / \mathrm{kg}$, was the predominant carbohydrate. The major part of the hemicellulosic saccharides in algae might probably be alginate as well as sulfated polysaccharides such as agar and carageenan, as they were reported to be the major structural polysaccharide of algae, for instance, brown and red algae. ${ }^{25,26}$ The lowest hemicellulose contents were found in the aquatic plants, for instance, sennin-mo (No.20) and kokanada-mo (No.23) with, respectively, 88 and $93 \mathrm{~g} / \mathrm{kg}$. The detailed monosaccharides composition will be discussed later.

As a carbohydrate, starch was a minor component in all the biomass samples studied. The lowest value was found in Japanese cedar (No.1) with $1 \mathrm{~g} / \mathrm{kg}$ and the highest in oil palm trunk (No.16) to be $29 \mathrm{~g} / \mathrm{kg}$. A similar content of starch in oil palm to be $17 \mathrm{~g} / \mathrm{kg}$ was previously reported. ${ }^{27}$

Lignin as the sum of Klason lignin and acid-soluble lignin was the highest in softwood Japanese cedar (No.1) with $331 \mathrm{~g} / \mathrm{kg}$, whereas it was inexistent in 3 of the algae species studied, namely spirulina (No.32), chlorella (No.30) and chladophora (No.27). In the other aquatic samples, lignin ranged from 18 for euchemia (No.31) to $175 \mathrm{~g} / \mathrm{kg}$ for parrot feather (No.3), whereas in the terrestrial ones, it varied from 151 for corn leaves (No.8) to $331 \mathrm{~g} / \mathrm{kg}$ for Japanese cedar (No.1). Among the biomass species studied, lignin content was, therefore, lower in the aquatic samples and particularly in the marine algae as compared to the terrestrial ones. Since the roles of hydrophobic lignin are mostly to provide mechanical strength to the cell walls and to conduct water without its leaking from the cell walls, such properties are mostly important for terrestrial plants, but not for aquatic plants and algae. This might be the reason of the difference in the lignin content.

It was historically considered that algae and seaweeds did not contain lignin but recent publications questioned such belief and lignin distribution in plant kingdom is currently under reevaluation. $^{28,29}$ First, "lignin-like compounds" have been identified in primitive green algae. ${ }^{30-31}$ Later on, an anatomical and structural study on the red alga Calliarthron revealed the presence of secondary walls and true lignin in that species, suggesting a convergent evolution of cell wall structure or a deeply conserved evolutionary history of these traits. ${ }^{32}$ Evidence was also provided to prove that the red alga contained guaiacyl propane, $p$-hydroxyphenylpropane as well as syringyl propane units. ${ }^{32}$ Other studies reported some lignin contents in the green alga sea lettuce to be $15 \mathrm{~g} / \mathrm{kg}^{33}$ and in brown algae including sargassum species to be between 141 and $175 \mathrm{~g} / \mathrm{kg} .{ }^{34}$ In this study, Klason lignin contents of brown algae, namely akamoku (No.24) and sargassum (No.25), as well as green algae, specifically sea lettuce (No.26), caulerpa (No.28) and sea grape (No.29), in addition to euchemia (No.31) as a red alga were, respectively, $142,73,33,37,26$ and $18 \mathrm{~g} / \mathrm{kg}$, after ash and protein corrections, as in Table 2. Further evidence on the existence of lignin in these samples will be discussed later. Such finding on the lignin content of algae can, therefore, be a meaningfully supportive data on the study of cell wall evolution of plants.

The determination of protein content of biomass is important since this constituent can be considered as a substrate for proteinbased value-added products but it might also affect the choice of a biomass for a given application. Depending on the applications, protein in the feedstock might be desirable or not. Whilst protein was very high in spirulina (No.32) and chlorella (No.30) with respectively 502 and $423 \mathrm{~g} / \mathrm{kg}$, the samples analyzed with green leaves such as aquatic plants growing in lakes (Nos.3,19-23), brown and green algae (No.24-No.30) and corn leaves (No.8) also presented high amounts of protein. High protein content in these samples was probably due to the presence of photosynthetic pigment-protein complex present in the biomass leaves. The other biomass studied had their protein contents equal to or below 261 $\mathrm{g} / \mathrm{kg}$. However, protein content greatly varied among samples taken from different parts of the same plant, for instance, protein in corn leaves (No.8) to be $165 \mathrm{~g} / \mathrm{kg}$ was much higher than that of the corn cob (No.9) of the same corn plant to be $58 \mathrm{~g} / \mathrm{kg}$. Similarly, rice straw (No.5) had higher protein than rice husk (No.6) of the same rice plant. Those results suggest that protein might be concentrated in the leaves of those photosynthetic organisms.

Extractives mostly consist of low molecular compounds soluble in liquids of low polarity. Extractives from woods were found to present undesirable effects on pulp and papermaking. ${ }^{35,36}$ Similar trends are also expected in other biorefinery applications. Thus, acetone extractives were also studied in the biomass. Chladophora (No.27) and chlorella (No.30) presented the least acetone extractives, while akamoku (No.24) had the highest one to be $96 \mathrm{~g} / \mathrm{kg}$. The amounts of extractives varied among the biomass species studied and even within different parts of the same plant. As an example, rice straw (No.5) presented $45 \mathrm{~g} / \mathrm{kg}$ of extractives, whereas rice husk (No.6) from the same plant had $13 \mathrm{~g} / \mathrm{kg}$. A similar result was found for corn leaves and cob (Nos.8 and 9) with respectively 51 and $28 \mathrm{~g} / \mathrm{kg}$. The other biomass species studied had their extractives ranged between 10 and $75 \mathrm{~g} / \mathrm{kg}$.

The inorganics present in the biomass were analyzed as ash. 
The values fluctuated greatly among the samples studied. While Japanese cedar (No.1) had the lowest ash content with only 3 $\mathrm{g} / \mathrm{kg}$, the highest values were found in aquatic species such as sea grape (No.29) with $500 \mathrm{~g} / \mathrm{kg}$, followed by chladophora (No.27), sea lettuce (No.26), akamoku (No.24) and kuro-mo (No.22) with, respectively, 402, 257, 229 and $223 \mathrm{~g} / \mathrm{kg}$. Sargassum and some aquatic plants were proved to have the capacity to intake minerals and heavy metals from the water they grow in, ${ }^{37,38}$ such a property might explain their high ash contents. Among the terrestrial plants studied, rice husk (No.6) had the highest ash content with $168 \mathrm{~g} / \mathrm{kg}$. In the literature, ash contents in rice husk vary from 143 to $170 \mathrm{~g} / \mathrm{kg}$ and such high ash contents were reported to be due to high silica content. ${ }^{39-41}$

Overall, the summative results comprised between 959 and $999 \mathrm{~g} / \mathrm{kg}$. The majority of all the biomass constituents were, therefore, identified. Although the chemical composition of the biomass species differed from a species to another, similarities were found in the composition of samples belonging to the same taxonomic group.

Apart from the chemical composition, the calorific values were studied. As a result, the calorific values of all the studied biomass species varied from $8.47 \mathrm{MJ} / \mathrm{kg}$ as in sea grape (No.29), to $23.48 \mathrm{MJ} / \mathrm{kg}$ as in chlorella (No.30). The higher plants (No.1No.23) presented similar trends in their calorific values which were accounted between 15.58 and $20.62 \mathrm{MJ} / \mathrm{kg}$, while for lower species (Nos.24-29, 31), the values were from 8.47 to 16.28 $\mathrm{MJ} / \mathrm{kg}$. Such low value could be explained by their high inorganic contents, determined as ash content in Table 2. Chlorella (No.30) was an exception among the Cryptogamae algae species since it presented the highest calorific value among all the studied samples. Such high calorific value is also reflected in its low ash content as shown in Table 2. The Eubacteria spirulina (No.32) also showed rather high calorific value as compared to the other algae species. From these lines of results, it became clear that the calorific value is also related to the taxonomy of the studied biomass.

\subsection{Monosaccharides composition of various biomass species}

Carbohydrates in biomass mainly consist of cellulose and hemicellulose which further comprise hexoses, pentoses and uronic acids. The detailed monosaccharides composition of biomass is necessary to determine their most suitable use, to evaluate the theoretical yields and to monitor the corresponding processes.

Therefore, hexoses, pentoses and uronic acid contents were studied in the biomass and the obtained results are shown in Table 3 which represents the monosaccharides composition of the biomass samples studied. Japanese cedar (No.1), representative of softwoods presented the highest glucose content among the assayed biomass species with $447 \mathrm{~g} / \mathrm{kg}$, followed by kokanadamo (No.23) with $422 \mathrm{~g} / \mathrm{kg}$, then by Japanese beech (No.2) and giant reed (No.15), both containing $417 \mathrm{~g} / \mathrm{kg}$ glucose and then erianthus (No.10) with $411 \mathrm{~g} / \mathrm{kg}$. Bagasse (No.12), wheat straw (No.7) and bamboo (No.4) presented similar glucose contents to be, respectively, 407, 406 and $402 \mathrm{~g} / \mathrm{kg}$. The other biomass species had their glucose contents equal to or below $392 \mathrm{~g} / \mathrm{kg}$. The glucose content is actually reflected in the cellulose content, as reported in Table 2 .
Types and proportion of the other various hemicellulosic monosaccharides showed a wide variation range among the biomass studied. Mannose was the highest in softwood Japanese cedar (No.1) to be $57 \mathrm{~g} / \mathrm{kg}$, most probably coming from its mannan. Parrot feather (No.3) and kokanada-mo (No.23) had mannose as their predominant hemicellulosic saccharides, while the other samples had their mannose content lower than $20 \mathrm{~g} / \mathrm{kg}$.

Galactose was particularly high in the red alga euchemia (No.31) to be $337 \mathrm{~g} / \mathrm{kg}$, most probably derived from agar which is a sulfated polysaccharide, typical for red algae, and composed of agarose and agaropectin. Agarose is the principal component of agar and consists of a repeating monomeric unit of agarobiose which is a disaccharide composed of D-galactose and 3,6anhydro-L-galactopyranose. ${ }^{42,43}$ In general, agaropectin contains similar sugars, but in addition has sulfate bound in ester linkage to the number of carbon six of the galactopyranose units and carboxylic acid groups resulting from the attachment of pyruvic acid groups via 0 -glycosidic linkages. D-Glucuronic acid has also been reported to be present. $^{42}$ Another sulfated polysaccharide present in red alga cell wall is carageenan, a galactan composed majoritarily of D-galactose units. ${ }^{43}$ Thus, the high galactose content in euchemia (No.31) may reflect its content in agar and carageenan. Among the other species studied, chlorella (No.30) had quite high galactose content as well, most likely coming from its galactan. ${ }^{44}$ The other species had their galactose equal to or below $120 \mathrm{~g} / \mathrm{kg}$.

Sea lettuce (No.26) showed rhamnose as its predominant neutral monosaccharide with $124 \mathrm{~g} / \mathrm{kg}$. A similar range was also reported elsewhere for another species of sea lettuce (Ulva pertusa) to be $137 \mathrm{~g} / \mathrm{kg} .{ }^{45}$ Such high rhamnose might be coming from the polysaccharide ulvan which is specific for green algae species and known to be composed mainly of rhamnose. ${ }^{46}$ Other green algae such as chladophora (No.27) and caulerpa (No.28) also had relatively high rhamnose content as compared to the rest of the biomass samples studied, while terrestrial monocotyledonous angiosperm species (No.4-No.18) had quite low rhamnose content to be equal to or lower than $5 \mathrm{~g} / \mathrm{kg}$. Fructose could be detected only in aquatic plants that are parrot feather (No.3), sennin-mo (No.20), okanada-mo (No.21) and kuro-mo (No.22) with 22, 3, 1 and $1 \mathrm{~g} / \mathrm{kg}$, respectively.

Corn cob and bagasse (Nos. 8 and 9) were remarkable for their high xylose content to be, respectively, 312 and $260 \mathrm{~g} / \mathrm{kg}$. Such a high xylose content could also be observed elsewhere for corn cob. ${ }^{39}$ However, not only corn cob and bagasse but all the monocotyledonous species studied, belonging to Poaceae family, as known as Gramineae (No.4-No.15), had their xylose relatively higher as compared to the lower plants, most probably due to their high xylan content. ${ }^{47}$ Species belonging to the Aracaceae family, usually known as Palmae family (No.16-No.18) also showed relatively high xylose contents, similar to the ones of Gramineae. Conversely, the aquatic monocotyledonous species, belonging to Pontederiaceae (No.19), Potamogetonaceae (No.20) and

Hydrocharitaceae (No.21) families showed rather low xylose content to be between 21 and $58 \mathrm{~g} / \mathrm{kg}$.

Dicotyledonous Japanese beech (No.2) had its xylose content in similar range as the ones of the Poaceae monocotyledonous species (No.4-No.15), while dicotyledonous 
parrot feather (No.3), which is an aquatic plant, had very low xylose content to be $32 \mathrm{~g} / \mathrm{kg}$, similar to the monocotyledonous aquatic plants (No.20-No.23). From those results, it seems that the aquatic plants belonging to the Phanerogamae (Nos.3,19-23) were similar in their xylose content. Similarly, the terrestrial angiosperm in Phanerogamae also showed comparable ranges of xylose

content. 
Table 3 Monosaccharides composition of the biomass samples studied ( $\mathrm{g} / \mathrm{kg}$ of the original oven-dried biomass basis)

\begin{tabular}{|c|c|c|c|c|c|c|c|c|c|c|}
\hline \multirow[b]{2}{*}{ Family } & \multirow[b]{2}{*}{$\begin{array}{l}\text { Sample } \\
\text { No. }\end{array}$} & \multirow[b]{2}{*}{ Biomass } & \multicolumn{5}{|c|}{ Hexoses } & \multicolumn{2}{|c|}{ Pentoses } & \multirow{2}{*}{$\begin{array}{l}\text { Uronic } \\
\text { acid }\end{array}$} \\
\hline & & & Glc & Man & Gal & $\mathrm{Rhm}$ & Fru & Xyl & Ara & \\
\hline $\begin{array}{l}\text { Cupressaceae } \\
\text { (softwood) }\end{array}$ & 1 & Japanese cedar & 447 & 57 & 12 & 2 & 0 & 64 & 6 & 9 \\
\hline $\begin{array}{l}\text { Fagaceae } \\
\text { (hardwood) }\end{array}$ & 2 & Japanese beech & 417 & 14 & 36 & 23 & 0 & 213 & 9 & 20 \\
\hline Haloragaceae & 3 & $\begin{array}{l}\text { Parrot feather (aquatic } \\
\text { plant) }\end{array}$ & 289 & 41 & 24 & 13 & 22 & 32 & 37 & 16 \\
\hline \multirow{12}{*}{$\begin{array}{l}\text { Poaceae } \\
\text { (Gramineae) }\end{array}$} & 4 & Bamboo & 402 & 5 & 32 & 3 & 0 & 234 & 42 & 9 \\
\hline & 5 & Rice straw & 355 & 3 & 12 & 3 & 0 & 216 & 30 & 7 \\
\hline & 6 & Rice husk & 349 & 2 & 17 & 3 & 0 & 178 & 21 & 4 \\
\hline & 7 & Wheat straw & 406 & 1 & 7 & 2 & 0 & 179 & 25 & 27 \\
\hline & 8 & Corn leaves & 268 & 1 & 8 & 5 & 0 & 169 & 27 & 8 \\
\hline & 9 & Corn cob & 344 & 1 & 14 & 2 & 0 & 312 & 54 & 13 \\
\hline & 10 & Erianthus & 411 & 1 & 5 & 1 & 0 & 177 & 20 & 3 \\
\hline & 11 & Miscanthus & 382 & 1 & 6 & 2 & 0 & 190 & 29 & 4 \\
\hline & 12 & Bagasse & 407 & 0 & 5 & 1 & 0 & 260 & 15 & 13 \\
\hline & 13 & Sugarcane leaves & 335 & 3 & 7 & 1 & 0 & 210 & 23 & 9 \\
\hline & 14 & Common reed & 360 & 0 & 4 & 2 & 0 & 244 & 24 & 6 \\
\hline & 15 & Giant reed & 417 & 0 & 2 & 1 & 0 & 226 & 16 & 5 \\
\hline \multirow{3}{*}{$\begin{array}{l}\text { Aracaceae } \\
\text { (Palmae) }\end{array}$} & 16 & Oil palm trunk & 338 & 11 & 8 & 4 & 0 & 220 & 38 & 17 \\
\hline & 17 & Nipa frond & 392 & 10 & 19 & 2 & 0 & 175 & 27 & 33 \\
\hline & 18 & Sugar palm frond & 392 & 1 & 6 & 3 & 0 & 182 & 23 & 14 \\
\hline $\begin{array}{l}\text { Pontederiaceae } \\
\text { (aquatic plants) }\end{array}$ & 19 & Water hyacinth & 163 & 0 & 98 & 13 & 0 & 44 & 40 & 131 \\
\hline $\begin{array}{l}\text { Potamogetonaceae } \\
\text { (aquatic plants) }\end{array}$ & 20 & Sennin-mo & 343 & 6 & 5 & 8 & 3 & 58 & 26 & 19 \\
\hline \multirow[t]{3}{*}{$\begin{array}{l}\text { Hydrocharitaceae } \\
\text { (aquatic plants) }\end{array}$} & 21 & Okanada-mo & 267 & 19 & 59 & 16 & 1 & 51 & 16 & 24 \\
\hline & 22 & Kuro-mo & 241 & 1 & 44 & 12 & 1 & 29 & 24 & 11 \\
\hline & 23 & Kokanada-mo & 422 & 31 & 26 & 8 & 0 & 25 & 14 & 26 \\
\hline \multirow{2}{*}{$\begin{array}{l}\text { Sargassaceae } \\
\text { (brown algae) }\end{array}$} & 24 & Akamoku & 55 & 15 & 25 & 0 & 0 & 6 & 0 & 203 \\
\hline & 25 & Sargassum & 230 & 4 & 120 & 2 & 0 & 85 & 0 & 230 \\
\hline \multirow{2}{*}{$\begin{array}{l}\text { Ulvaceae } \\
\text { (green algae) }\end{array}$} & 26 & Sea lettuce & 78 & 0 & 1 & 124 & 0 & 59 & 0 & 100 \\
\hline & 27 & Chladophora & 46 & 0 & 15 & 61 & 0 & 63 & 33 & 122 \\
\hline \multirow{2}{*}{$\begin{array}{l}\text { Caulerpaceae } \\
\text { (green algae) }\end{array}$} & 28 & Caulerpa & 90 & 0 & 67 & 47 & 0 & 207 & 22 & 4 \\
\hline & 29 & Sea grape & 66 & 14 & 30 & 2 & 0 & 129 & 0 & 7 \\
\hline $\begin{array}{l}\text { Chlorellaceae } \\
\text { (green algae) }\end{array}$ & 30 & Chlorella & 43 & 0 & 141 & 39 & 0 & 65 & 19 & 113 \\
\hline $\begin{array}{l}\text { Solieraceae (red } \\
\text { algae) }\end{array}$ & 31 & Euchemia & 64 & 0 & 337 & 21 & 0 & 20 & 0 & 350 \\
\hline $\begin{array}{l}\text { Pseudanabaenaceae } \\
\text { (blue-green algae) }\end{array}$ & 32 & Spirulina & 80 & 0 & 29 & 14 & 0 & 57 & 13 & 90 \\
\hline
\end{tabular}

Glc : Glucose, Man : Mannose, Gal : Galactose, Rhm : Rhamnose, Fru : Fructose, Xyl : Xylose, Ara : Arabinose 
Table 4 Molar ratio of syringaldehyde and $p$-hydroxybenzaldehyde to vanillin in the biomass samples studied as determined by alkaline nitrobenzene oxidation

\begin{tabular}{|c|c|c|c|c|c|c|}
\hline Family & $\begin{array}{l}\text { Sample } \\
\text { number }\end{array}$ & Species & Lignin $(g / k g)$ & Vanillin & Syringaldehyde & $p$-Hydroxybenzaldehyde \\
\hline $\begin{array}{l}\text { Cupressaceae } \\
\text { (softwood) }\end{array}$ & 1 & Japanese cedar & 331 & 1 & 0 & 0.05 \\
\hline \multirow{2}{*}{$\begin{array}{l}\begin{array}{l}\text { Fagaceae } \\
\text { (hardwood) } \\
\text { Haloragaceae }\end{array}\end{array}$} & 2 & Japanese beech & 240 & 1 & 2.00 & 0 \\
\hline & 3 & $\begin{array}{l}\text { Parrot feather (aquatic } \\
\text { plant) }\end{array}$ & 175 & 1 & 1.00 & 0.76 \\
\hline \multirow{12}{*}{$\begin{array}{l}\text { Poaceae } \\
\text { (Gramineae) }\end{array}$} & 4 & Bamboo & 206 & 1 & 1.28 & 0.45 \\
\hline & 5 & Rice straw & 202 & 1 & 0.67 & 0.52 \\
\hline & 6 & Rice husk & 241 & 1 & 0.15 & 0.23 \\
\hline & 7 & Wheat straw & 200 & 1 & 0.49 & 0.11 \\
\hline & 8 & Corn leaves & 151 & 1 & 0.65 & 0.56 \\
\hline & 9 & Corn cob & 180 & 1 & 0.64 & 0.77 \\
\hline & 10 & Erianthus & 254 & 1 & 0.66 & 0.13 \\
\hline & 11 & Miscanthus & 223 & 1 & 0.63 & 0.42 \\
\hline & 12 & Bagasse & 224 & 1 & 0.80 & 0.19 \\
\hline & 13 & Sugarcane leaves & 197 & 1 & 0.74 & 0.09 \\
\hline & 14 & Common reed & 202 & 1 & 1.03 & 0.14 \\
\hline & 15 & Giant reed & 249 & 1 & 1.09 & 0.23 \\
\hline \multirow{2}{*}{$\begin{array}{l}\text { Aracaceae } \\
\text { (Palmae) }\end{array}$} & 16 & Oil palm trunk & 282 & 1 & 3.50 & 0.00 \\
\hline & $\begin{array}{l}17 \\
18\end{array}$ & $\begin{array}{l}\text { Nipa frond } \\
\text { Sugar palm frond }\end{array}$ & $\begin{array}{l}196 \\
209\end{array}$ & $\begin{array}{l}1 \\
1\end{array}$ & $\begin{array}{l}1.20 \\
1.56\end{array}$ & $\begin{array}{l}0.03 \\
0.13\end{array}$ \\
\hline $\begin{array}{l}\text { Pontederiaceae } \\
\text { (aquatic plants) }\end{array}$ & 19 & Water Hyacinth & 101 & 1 & 0.84 & 0.67 \\
\hline $\begin{array}{l}\text { Potamogetonaceae } \\
\text { (aquatic plants) }\end{array}$ & 20 & Sennin-mo & 149 & 1 & 1.43 & 2.47 \\
\hline \multirow[t]{3}{*}{$\begin{array}{l}\text { Hydrocharitaceae } \\
\text { (aquatic plants) }\end{array}$} & 21 & Okanada-mo & 71 & 1 & 1.15 & 2.01 \\
\hline & 22 & Kuro-mo & 79 & 1 & 1.26 & 1.76 \\
\hline & 23 & Kokanada-mo & 76 & 1 & 0.70 & 0.93 \\
\hline \multirow[t]{2}{*}{$\begin{array}{l}\text { Sargassaceae } \\
\text { (brown algae) }\end{array}$} & 24 & Akamoku & 142 & 1 & 0.23 & 2.70 \\
\hline & 25 & Sargassum & 73 & 1 & 0.44 & 2.40 \\
\hline \multirow[t]{2}{*}{$\begin{array}{l}\text { Ulvaceae } \\
\text { (green algae) }\end{array}$} & 26 & Sea lettuce & 33 & 1 & 1.36 & 0.11 \\
\hline & 27 & Chladophora & 0 & 0 & 0 & 0 \\
\hline \multirow[t]{2}{*}{$\begin{array}{l}\text { Caulerpaceae } \\
\text { (green algae) }\end{array}$} & 28 & Caulerpa & 37 & 1 & 1.25 & 1.95 \\
\hline & 29 & Sea grape & 26 & 1 & 1.13 & 1.78 \\
\hline $\begin{array}{l}\text { Chlorellaceae } \\
\text { (green algae) }\end{array}$ & 30 & Chlorella & 0 & 0 & 0 & 0 \\
\hline $\begin{array}{l}\text { Solieraceae (red } \\
\text { algae) }\end{array}$ & 31 & Eucheumia & 18 & 1 & 1.24 & 0.90 \\
\hline $\begin{array}{l}\text { Pseudanabaenaceae } \\
\text { (blue-green algae) }\end{array}$ & 32 & Spirulina & 0 & 0 & 0 & 0 \\
\hline
\end{tabular}


As for the lower plants, their xylose content was equal or inferior to $85 \mathrm{~g} / \mathrm{kg}$, except for caulerpa (No.28) and sea grape (No.29) which showed relatively high xylose content, to be 207 and 129 $\mathrm{g} / \mathrm{kg}$, respectively.

Arabinose varied from 0 to $54 \mathrm{~g} / \mathrm{kg}$ for all the biomass samples studied. The highest content was found in corn cob (No.9), while arabinose was absent in the brown algae (Nos.24 and 25) studied and some green algae, namely sea lettuce (No.26) and sea grape (No.29) as well as in the red alga euchemia (No.31). Among the higher plants, the Poaceae species (No.4-No.15) studied presented relatively higher arabinose content as compared to wood species (Nos.1 and 2). Since xylose is also high in Poaceae, the arabinose might come from the arabinoxylan, known to be the major hemicellulose in that family. ${ }^{48}$

The algae species had significantly high uronic acid content, up to $350 \mathrm{~g} / \mathrm{kg}$ for the red alga euchemia (No.31), followed by the brown algae sargassum (No.25) and akamoku (No.24), with 230 and $203 \mathrm{~g} / \mathrm{kg}$, respectively. For the red alga euchemia (No.31), such high uronic acid content might be due to the agaropectin, ${ }^{42}$ while in the brown algae sargassum (No.25) and akamoku (No.24), such high uronic acid might come from their alginate which is a glycuronan consisting of residues of D-mannuronic acid and L-guluronic acid. ${ }^{49}$ The other biomass species studied had their uronic acid content lower or equal to $131 \mathrm{~g} / \mathrm{kg}$.

Altogether, the differences and similarities in the monosaccharides composition of biomass samples studied reflected well their taxonomy.

\subsection{Phenylpropane units of lignin}

The chemical structure of lignin in the biomass samples was examined and the obtained results are shown in Table 4 which reveals the molar ratio of syringaldehyde and $p$ hydroxybenzaldehyde to vanillin in the studied biomass species as determined by alkaline nitrobenzene oxidation where vanillin, syringaldehyde and $p$-hydroxybenzaldehyde correspond respectively to the guaiacyl type lignin unit $(G)$, syringyl type lignin unit $(\mathrm{S})$ and to the $p$-hydroxyphenyl propane unit $(\mathrm{P})$.

As expected, Japanese cedar (No.1), representing softwood showed mainly $\mathrm{G}$ moiety, with small ratio of the $\mathrm{P}$ one, while dicotyledonous hardwood Japanese beech (No.2) presented G and $\mathrm{S}$ moieties only. Gramineae species yielded all 3 moieties in fluctuating molar ratios, which is in accordance with previous findings suggesting that $\mathrm{P}$ unit might be the distinguishing characteristics of monocotyledon. ${ }^{50}$ Interestingly, as an aquatic dicotyledonous species, parrot feather (No.3) also showed all 3 aldehydes, implying that the chemical structure of its lignin would be more similar to the one of monocotyledonous species, rather than the one of wood, which is the most representative of dicotyledons.

Among the monocotyledonous palm species, nipa frond (No.17) and sugar palm frond (No.18) presented the 3 moieties, with very small quantity of $\mathrm{P}$, whereas oil palm trunk (No.16) yielded only $G$ and $S$ units. The relatively large occurrence of $S$ moiety to range from molar ratios of 1.2 to 3.5 in the palm species suggests that palm lignin could be similar to hardwood lignin. However, the presence of $\mathrm{P}$ in nipa frond and sugar palm frond suggests that their lignin structure would be more similar to the ones of Graminae. Other researchers showed that $\mathrm{P}$ from palm species can be detected in small quantities or not detected at all, and, thus, would not be a distinctive factor. ${ }^{51-54}$

Concerning aquatic species, the samples containing lignin could yield all 3 moieties in different molar ratios. $p$ Hydroxybenzaldehyde was even predominant in sennin-mo (No.20), okanada-mo (No.21), kuromo (No.22), akamoku (No.24), sargassum (No.25), caulerpa (No.28) and sea grape (No.29). It was reported for herbaceous samples that a large proportion of $p$-hydroxybenzaldehyde and vanillin produced after the alkaline nitrobenzene oxidation could be formed respectively from $p$-coumaric acid and ferulic acid esterified or etherified with lignin, and not from $\mathrm{P}$ and $\mathrm{G}$ moieties in the lignin polymer itself. $^{22}$

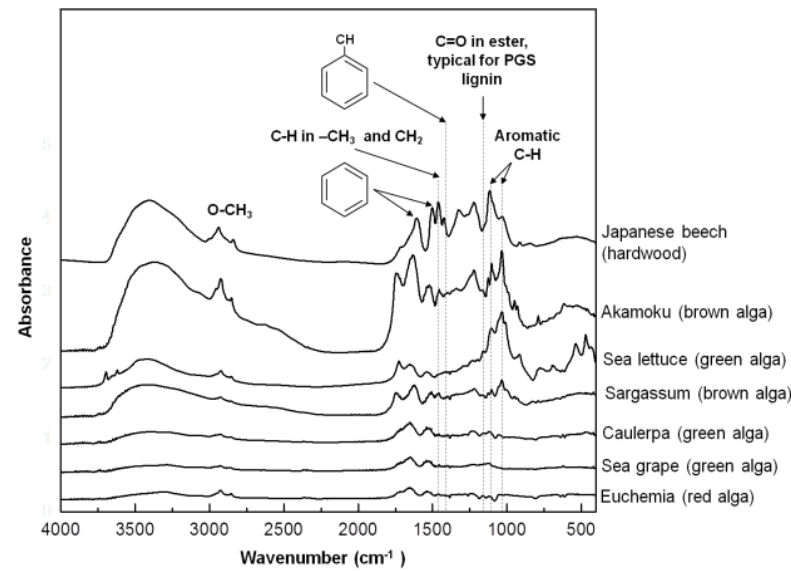

Fig. 3 FT-IR spectra of crude Klason lignins from algae species as compared to the one from Japanese beech (Fagus crenata)

In order to confirm the presence of the 3 moeities in those algae species, FT-IR spectra of the crude Klason lignin of 2 brown algae that are akamoku (No.24) and sargassum (No.25), 3 green algae which are sea lettuce (No.26), caulerpa (No.28) and sea grape (No.29) as well as a red alga named euchemia (No.31) were studied.

As a result, Fig. 3 shows the FT-IR spectra of crude Klason lignins from the algae species as compared to the one from Japanese beech (No.2).

The absorption spectra for the algae studied, except for akamoku, showed quite lower intensity, most probably due to their low lignin content but also to the remaining inorganics and protein in the crude Klason lignin residues. However, the algae species, together with Japanese beech showed absorption bands between 2939-2842 $\mathrm{cm}^{-1}$, which correspond to $\mathrm{C}-\mathrm{H}$ stretch ${ }^{55}$ as well as methoxyl group bands between $2965-2945 \mathrm{~cm}^{-1} .56$ They also presented absorption bands in the regions $1593-1605 \mathrm{~cm}^{-1}$ and $1515-1505 \mathrm{~cm}^{-1}$, both of which coming from aromatic skeletal vibrations, typical for lignin $^{55}$ and positive peaks at 1460-1470 $\mathrm{cm}^{-1}$ assigned to $-\mathrm{CH}$ deformations in $-\mathrm{CH}_{3}$ and $-\mathrm{CH}_{2}-$. A band in the range $1422-1430 \mathrm{~cm}^{-1}$, proof of the presence of aromatic skeletal vibration combined with $-\mathrm{CH}$ in plane deformation ${ }^{55}$ is also present in the algae as well as Japanese beech. 
Finally, although in rather low intensities, absorption bands at $1160-1166 \mathrm{~cm}^{-1}$, representing $-\mathrm{C}=\mathrm{O}$ in ester, typical for $\mathrm{P}, \mathrm{G}$ and $\mathrm{S}$ type lignin ${ }^{55}$, were also present in spectra of the algae studied but missing in the one of Japanese beech. Such lines of evidence confirm that these 6 algae studied presented lignin of P, $\mathrm{G}$ and $\mathrm{S}$ types. Therefore, the results on the lignin properties of algae from this work complete those of Martone et al. ${ }^{32}$ for instance concerning the presence of $\mathrm{S}$ type lignin in some algae species, which is quite a noticeable breakthrough. Such findings are surely important for further studies on lignin distribution among living organisms but also for further understanding of the cell wall evolution over the plant kingdom.

\subsection{Cluster analysis of biomass}

All 32 biomass samples of different origin were used for a cluster analysis by principal component analysis (PCA). The 7 features used were the contents of cellulose, hemicellulose, lignin, protein, extractives, starch and ash.

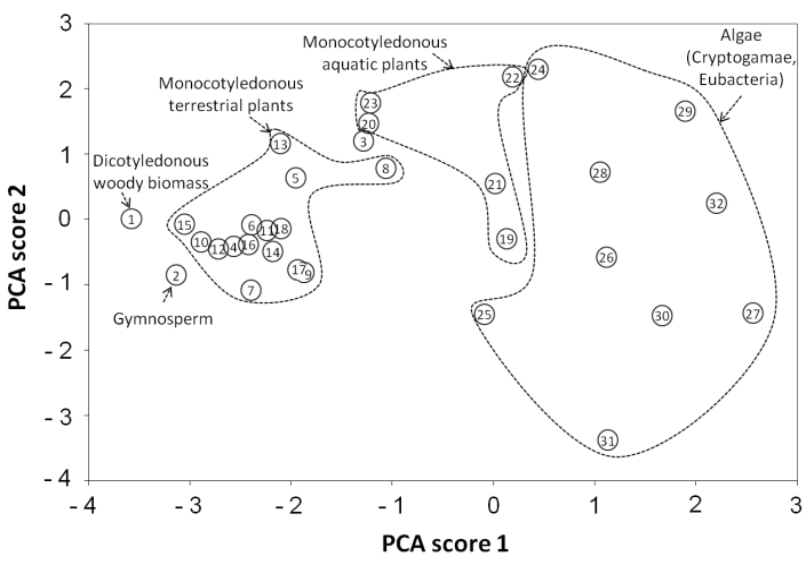

Fig. 4 PCA score plot for the 32 biomass samples characterized by their contents in cellulose, hemicellulose, lignin, protein, extractives, starch and ash.

Figure 4 shows the resulting scatter plot using the scores of the first 2 principal components, preserving 44.6 and $23.6 \%$ of the total variance, respectively. Woody biomass represented by Japanese cedar (No. 1) and Japanese beech (No.2) were relatively close in the clustering but appeared to be respectively quite apart from the other samples. The monocotyledonous terrestrial plants including Gramineae (No.4-No.15) and palm species (No.16No.18) built a relative compact cluster, while the other samples were rather diverse. The monocotyledonous aquatic plants (No.20-No.23) formed an intermediate cluster between the higher plants and the lower ones. The algae species represented by Cryptogamae (No.24-No.31) and Eubacteria (No.32) samples formed a different cluster on the right, reflecting their different composition from the other plant materials.

The results from the cluster analysis demonstrate that the chemical composition of the biomass species is related to the taxonomic classification.

\subsection{Chemical composition of various biomass species in relation with their taxonomic classification and their potential for different biorefinery platforms}

As discussed previously, although the chemical composition of the biomass species differed from a species to another, similarities were found in the composition of samples belonging to the same taxonomic group. Therefore, representatives of each predominant taxonomic group were selected and represented in Fig. 5 which shows the chemical composition of the biomass species studied according to their taxonomic classification.

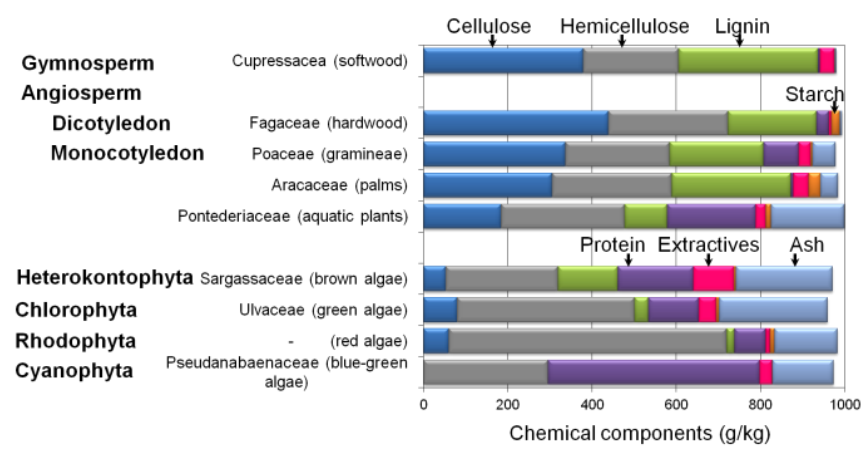

Fig. 5 Chemical composition of various biomass species in relation with their taxonomic classification

From Fig. 5, it became more obvious that chemical composition of the lower plants is very different from the higher ones. In the lower plants including Heterokontophyta, Chlorophyta, Rhodophyta and Cyanophyta, the carbohydrates are characterized by the inexistence or low range of cellulose but high hemicellulose content with acid sugars. Such a pattern changes in the higher plants where cellulose content is high. Lignin is also inexistent or low in the lower plants and became higher over the evolution.

Such differences in the chemical composition of the lower plants and higher ones reflect the taxonomy of the samples as well as the evolution theory presented in Fig. 1 as lignin and hemicellulose were modified over the evolution.

From the revealed classification in the chemical composition of the various biomass species and their calorific values, it is possible to determine the potential of each taxonomic group for various biorefinery platforms. Table 5 shows the potential of the diverse taxonomic groups of biomass for combustion and for different biorefinery platforms which were determined by Werpy et al in the model of biobased product flowchart. ${ }^{57}$

According to the chemical composition, gymnosperm species showed very high potential for syngas and lignin as well as high potential for sugar platform and for combustion. A similar pattern can be seen for dicotyledonous hardwood, with very high potential for sugar platform. Gramineae and palm species showed similar potential for syngas, sugar and lignin platforms as well as for combustion but the potential of the Gramineae for protein platform was superior to the one of palm species. Finally, the monocotyledonous aquatic plants showed more or less similar trends with the algae groups in their potential for biorefinery applications. 
Table 5 Potential of the various taxonomic groups of biomass for different biorefinery platforms and for combustion

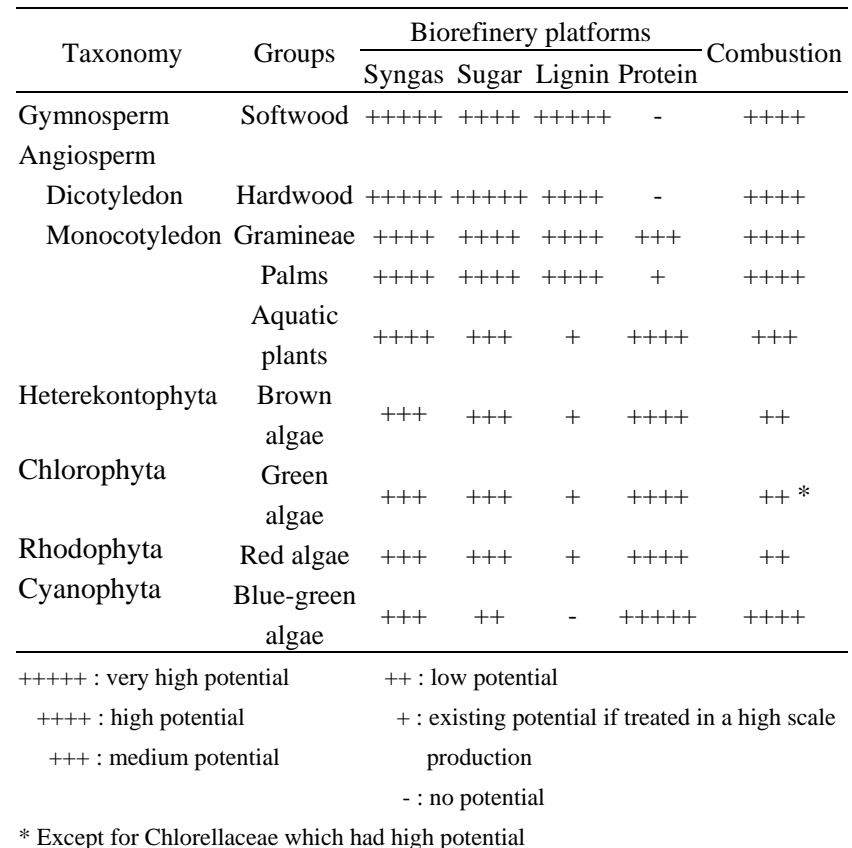

\section{Conclusions}

The chemical composition of 32 biomass samples belonging to 29 species could be revealed in this work. The results showed that the chemical composition of the examined samples differed from a species to another but also from different parts of the same plant. However, similarities were found in species belonging to the same family, allowing the establishment of typical chemical composition of the significant taxonomic groups of plants and algae species to be potentially used for green chemistry and biorefinery. Conclusively, this characterization study is a very important tool and basis to develop efficient biorefinery strategies.

\section{Acknowledgment}

This work was supported by the Ministry of Education, Culture, Sports, Science and Technology of Japan via the Global Center of Excellence (GCOE) program "Energy Science in the Age of Global Warming". The authors are also grateful to all individuals and companies that kindly provided or contributed to the collection of the biomass samples for this study.

\section{References}

1. I. Inouye and N. Okamoto, Plant Biotechnology, 2005, 22, 505-514.

2. M. Ek and G. Gellerstedt, in Pulp and paper chemistry and technology, eds. M. Ek, G. Gellerstedt and G. Henriksson, de Gryuter, Berlin, 2009, vol. Volume 1, pp. 1-9.

3. R. H. Whittaker, Communities and Ecosystems, The Macmillan Company, New York, 1970.
4. UNEP, Converting Waste Agricultural Biomass into a Resource Compendium of Technologies, United Nations Environmental Programme Division of Technology, Industry and Economics, 2009.

5. UNEP, Using Agricultural Biomass Waste for Energy and Materials: Resource Conservation and GHG Emission Reduction, A Biomass Assessment and Compendium of Technologies Project, 2007.

6. S. V. Vassilev, D. Baxter, L. K. Andersen and C. G. Vassileva, Fuel, 2009, 89, 913-933.

7. D. Lee, N. O. Vance, A. Boe and P. Jeranyama, Composition of herbaceous biomass feedstocks, Sun Grant Initiative, South Dakota State University, Brookings, 2007.

8. US Department of Energy, Biomass Feedstocks Composition and Property D atabase, http://www.afdc.energy.gov/biomass/progs/search1.cgi. Accessed 07/07/2012, 2012.

9. R. C. Pettersen, in The Chemistry of Solid Wood. Advances in chemistry vol.207, ed. R. M. Rowell, American Chemical Society, Washington, 1984, vol. 207, pp. 57-126.

10. E. Sjöstrom and R. Alen, Analytical Methods in Wood Chemistry, Pulping, and Papermaking, eds. E. Sjöstrom and R. Alen, Springer, Berlin, 1999.

11. K. Kuroda, in Mokushitsu kagaku jikken manual, ed. H. Yoshida, Buneido shuppan, Tokyo, 2000, pp. 87-98.

12. E. M. Hodgson, S. J. Lister, A. V. Bridgwater, J. Clifton-Brown and I. S. Donnison, Biomass and Bioenergy, 2010, 34, 652-660.

13. H. K. Goering and P. J. Van Soest, in USDA Agricultural Handbook No. 379, 1970, pp. 1-20.

14. A. T. Adesogan, D. I. Givens and E. Owen, in Field and laboratory methods for grassland and animal production research, eds. $\mathrm{L}$. Mannetje and R. M. Jones, CABI Publishing, Wallingford, 2000, pp. 263-278.

15. O. Theander, Animal Feed Science and Technology, 1991, 32, 35-44.

16. H. Rabemanolontsoa, S. Ayada and S. Saka, Biomass and Bioenergy, 2011, 35, 4630-4635.

17. H. Rabemanolontsoa and S. Saka, in Zero-Carbon Energy Kyoto 2011, ed. T. Yao, Springer Japan, Tokyo, 2012, pp. 135-140.

18. K. Yoshihara, T. Kobayashi, T. Fujii and I. Akamatsu, Japan Tappi Journal, 1984, 38, 466-475.

19. R. L. Whistler, in Methods in carbohydrate chemistry, eds. R. L. Whistler and M. L. Wolfrom, Academic Press, New York, 1962, pp. 56-87.

20. H. Rabemanolontsoa, S. Ayada and S. Saka, in Green energy and technology: Zero-Carbon Energy Kyoto 2010, ed. T. Yao, Springer, Kyoto, 2011, pp. 123-128.

21. A. Sundberg, K. Sundberg, C. Lillandt and Å. Holmbom, Nordic Pulp Paper Research Journal, 1996, 216-220.

22. K. Iiyama and T. B. T. Lam, Journal of Science of Food and Agriculture, 1990, 51, 481-491.

23. F. R. Humphreys and J. Kelly, Analytica Chimica Acta, 1961, 24, 6670.

24. N. J. Thiex, H. Manson, S. Anderson and J. A. Persson, Journal of AOAC International, 2002, 85, 309-317.

25. J. Gorham and S. A. Lewey, Marine Biology, 1984, 80, 103-107.

26. E. L. McCandless, in The biology of seaweeds, eds. C. S. Lobban and M. J. Wynne, Blackwell scientific publications, Oxford, 1981, pp. 559-588.

27. P. S. H`ng, L. J. Wong, K. L. Chin, E. S. Tor, S. E. Tan, B. T. Tey and M. Maminski, Journal of Applied Sciences, 2011, 11, 3053-3057.

28. N. G. Lewis and E. Yamamoto, Annual Review of Plant Physiology and Plant Molecular Biology, 1990, 41, 455-496.

29. E. Novo-Uzal, F. Pomar, L. V. G. Gómez Ros, J. M. Espiňeira and A. Ros Barceló, in Lignin: Biosynthesis, Biodegradation and Bioengineering, eds. L. Jouanin and C. Lapierre, Academic Press, Elsevier, 2012, vol. 61, pp. 312-241.

30. C. F. Delwiche, L. E. Graham and N. Thomson, Science, 1989, 245, 399-401.

31. D. Gunnison and M. Alexander, Journal of Applied Microbiology, 1975, 29, 729-738.

32. P. T. Martone, J. M. Estevez, F. C. Lu, K. Ruel, M. W. Denny, C. Somerville and J. Ralph, Current Biology, 2009, 19, 169-175. 
33. J. P. Sitompul, A. Bayu, T. H. Soerawidjaja and H. W. Lee, International Journal of Environment and Bioenergy, 2012, 3, 132144.

34. L. B. Malihan, G. M. Nisola and W.-J. Chung, Bioresource Technology, 2012, 118, 545-552.

35. H. Palonen, P. Stenius and G. Strom, Svensk Papperstidning-Nordisk Cellulosa, 1982, 85, R93-R99.

36. N. Garoff, S. Jernberg, N. O. Nilvebrant, C. Fellers and M. Backstrom, Tappi International Paper Physics Conference, 1999, 479-490.

37. P. Miretzky, A. Saralegui and A. F. Cirelli, Chemosphere, 2004, 57, 997-1005.

38. E. Fourest and B. Volesky, Environmental Science \& Technology, 1995, 30, 277-282.

39. J. C. Parajó, G. Garrote, J. M. Cruz and H. Dominguez, Trends in Food Science and Technology, 2004, 15, 115-120.

40. D. Nabarlatz, A. Ebringerova and D. Montane, Carbohydrate Polymers, 2007, 69, 20-28.

41. K. K. Krishnani, X. G. Meng, C. Christodoulatos and V. M. Boddu, Journal of Hazardous Materials, 2008, 153, 1222-1234.

42. C. Araki, Journal of the Chemical Society of Japan, 1937, 58, 13381350.

43. E. McCandless and J. Craigie, Annual review of plant physiology, 1979, 30, 41-53.

44. K. Ogawa and Y. Ikeda, Research Bulletin of Iwaki Meisei University, College of Science and Engineering, 2004, 17, 1-7.

45. Y. Pengzhan, Z. Quanbin, L. Ning, X. Zuhong, W. Yanmei and L. Zhi'en, Journal of Applied Phycology, 2003, 15, 21-27.

46. M. Lahaye and A. Robic, Biomacromolecules, 2007, 8, 1765-1774.

47. M. McNeil, A. G. Darvill, S. C. Fry and P. Albersheim, Annual Review of Biochemistry, 1984, 53, 625-663.

48. A. D. Evers, L. O'Brien and A. B. Blakeney, Australian Journal of Agricultural Research, 1999, 50, 629-650.

49. A. Haug, B. Larsen and O. Smidsrød, Carbohydrate Research, 1974, 32, 217-225.

50. R. H. J. Creighton, R. D. Gibbs and H. Hibbert, Journal of the American Chemical Society, 1944, 66, 32-37.

51. S. Suzuki, E. Rodriguez, K. Iiyama, K. Saito and H. Shintani, Journal of Wood Science, 1998, 44, 40-46.

52. R. C. Sun, J. M. Fang and J. Tomkinson, Journal of Wood Chemistry and Technology, 1999, 19, 335-356.

53. M. Shibata, M. Varman, Y. Tono, H. Miyafuji and S. Saka, Journal of the Japan Institute of Energy, 2008, 87, 383-388.

54. P. Tamunaidu and S. Saka, Industrial Crops and Products, 2011, 34, 1423-1428.

55. O. Faix, Holzforschung, 1991, 45, 21-28.

56. J. P. Blitz, R. S. S. Murthy and D. E. Leyden, Applied Spectroscopy, 1986, 40, 829-831.

57. T. Werpy, G. Petersen, A. Aden, J. Bozell, J. Holladay, J. White, A. Manheim, D. Eliot, L. Lasure and S. Jones, Top Value Added Chemicals From Biomass. Volume I: Results of Screening for Potential Candidates from Sugars and Synthesis Gas, Department of Energy, Washington D.C., 2004. 